\title{
GERİ DÖNÜŞÜMLÜ YAPAY SINIIR AĞI TABANLI T DALGASI SONU TESPİTİ
}

\author{
Mehmet İŞCAN ${ }^{1} *$ (iD), Aydın YEŞILLDİREK ${ }^{2}$ id \\ ${ }^{1,2}$ Mekatronik Mühendisliği, Ylldız Teknik Üniversitesi İstanbul, Türkiye
}

\begin{abstract}
ÖZET
Günümüzde yapay sinir ağlarının (YSA) kullanımı sınıflama işlemlerinden özel kalıplar tanımaya kadar birçok yerde karşımıza çıkmaktadır. Bu çalışmada, YSA tabanlı özgün bir algoritma ile kalp sağlığının önemli göstergelerinden biri olup, işaretlenmesi diğer EKG referans noktalarına göre güç olan T dalga sonunun tespiti önerilmiştir. Genel olarak, zamana bağlı sinyal serilerinin işlenmesinde ileri sinir ağları sınırlı başarı sağlanabildiğinden geri dönüşümlü YSA mimarisi kullanılmıştır. Önerilen algoritmanın etkinliğinin gösterimi için, PHYSIONET/QT veri tabanında bulunan tek kanaldan elde edilen EKG sinyalleri önişlemlere geçirilerek, kümeleme diyagramları ile T dalgasının son noktası sıkıştırılmış bir alana indirgenmiştir. Algoritmadan elde edilen sonuçlar, bu alanda standartlarda ifade edilen beklentilerin üzerinde bir performans sergilemiştir. 55'i eğitim atımı olan toplam 295 atımda mutlak olan hata değerlerinde $11.16 \pm 6.16$ milisaniye, mutlak olmayan hata değerlerinde ise $-4.70 \pm 6.64$ milisaniyelik iyi bir performansa ulaşılmıştır. Ayrıca geliştirilen bu yöntem, önceden eğitilmemiş ve uzmanlar tarafından işaretlenmiş 421 yeni atım üzerinde denendiğinde, $-6.40 \pm 17.22$ milisaniye gibi çok iyi bir mutlak olmayan işaretleme hata değerine ulaşılmıştır.
\end{abstract}

Anahtar kelimeler: Geri-Dönüşümlü sinir ağları, T dalgası sonu, Sinyal işleme, Sınıflama

\section{RECURRENT NEURAL NETWORK BASED T WAVE END DETECTION}

\begin{abstract}
Artificial neural networks (ANN) have been utilized in many areas such as classification, pattern discrimination, etc. In this study, a novel ANN based algorithm is proposed to detect T-wave end point, one of the important ECG signal parameters to determine heart health conditions that may be hardly marked with respect to the other ECG fiducial points. Since the feedforward neural networks (NN) applications in time series signal processing has a limited success, we adopt a recurrent NN architecture. To demonstrate the effectiveness of the algorithm, a set of single channel ECG signals obtained from PHYSIONET/QT database is preprocessed first, then using some clustering algorithms, the observation of the T wave end is sought within a limited time window. The algorithm is shown to reach a performance exceeding the expectations of the standards. It has been trained by 55 beats out of 295 and reaches the success rate of $11.16 \pm 6.16$ and $-4.70 \pm 6.64$ milliseconds error in terms of absolute and non-absolute conditions, respectively. Furthermore, the proposed algorithm has been retested on some other 421 ECG beats annotated by experts, where it had an excellent score of $-6.40 \pm 17.22$ milliseconds marking error.
\end{abstract}

Keywords: Recurrent neural network, T Wave end, Signal processing, Classification

\section{GİRİș}

Günümüzde kalp rahatsızlıklarına bağlı olarak oluşan can kayıpları toplam ölümlerin üçte birini oluşturmaktadır [1]. Kalp rahatsızlıklarının oluşumu genellikle genetik ve daha etkin olarak yaşam koşullarına bağlı (sigara tüketimi, ağır iş şartları, alkol tüketimi) tetiklenmektedir. Bunlardan dolayı araştırmacılar, kalbin fiziksel ve elektriksel karakteristiklerinin değiş̧iren ve düzensiz hale getiren bu değişimleri tespit etmek için çeşitli metotlar kullanmaktadır.

Bu yöntemlerden biri olan ve kalbin elektriksel aktivitesinin bir göstergesi olan elektrokardiyografi(EKG), kalbin belli bir vektör yönünde indüklenen voltaj karakteristiğinin bir göstergesidir ki bununla kalbin kasılan veya kasılmayan kısımlarının ayırt edilmesi gerçekleştirilebilmektedir [2]. Buna göre oluşan düzensizlikler EKG sinyali türünden farklılıklar içermekte ve bu farklılıkların tespiti yapılabilmektedir.

EKG’nin beş (P, Q, R, S, T) kalıp türlerinden biri olan T dalgası, kalbin ventriküllerinin gevşeme sürecini gösterdiği için uzmanlar tarafından kalpteki gevşeme bozukluklarının tahmininde sıkça kullanılmaktadır [3]. Kalbin gevşeme bozuklukları sıklıkla gevşeme zamanı, $\mathrm{T}$ dalgasının genlik değeri ve $\mathrm{T}$ dalgasının sınırlarının tespiti ile yapılmaktadır ve hepsi bazen ayrı 
ayrı, bazen ise toplam olarak işlenmekte ve hastalık tespitinde kullanılabilmektedir [4]. Buna bağlı olarak EKG sinyalinin işlenmesindeki en büyük problemlerden biri kalbin ventriküllerinin son noktasının tespiti (T dalgası sonu) olarak sayılmaktadır ve bunun ile alakalı pek çok çalışma yapılmıştır. Bu önemin sebebi ise gevşemenin son noktasının düşük frekans bandında bulunması, izoelektrik seviyenin sürekli değişmesi ve fizyolojik değişimlere ve hatta insandan insana değişimlere bağlı olarak sinyalin gürültü ve farklılığa uğraması gösterilebilmektedir [5].

Şu ana kadar yapılan çalışmalar farklı yöntemler kullanılarak $\mathrm{T}$ dalga sonu işaretlenmeye çalışılmıştır. Bu çalışmalardan türevsel [6,7], dalgacık ve fourier dönüşümü [8,9], deterministik olmayan modellerin uygulanması [10,11], ve deterministik olan modellerle kalıp eşlemeleri olarak sınıflandırılabilir [12,13]. Türevsel yöntemler gerçek zamanlı uygulamalar için uygun bir kullanım avantajı vermekte, ancak genlik ve gürültüye bağlı değişimlerde gürbüz performansını koruyamamaktadır. Frekans tabanlı işlemler için gürültülerin ayırılması ve sinyalin belirli frekans aralıklarında incelenmesi genlik ve zamana dair sorunları gidermiş, ancak düşük frekansa sahip gürültü değerlerinde ve özellikle düzensiz ritimlerde $T$ sonunu bulmayı zorlaştırmıştır. Bunlara istinaden kalıp uydurma ve matematiksel modellerle sinyallerin işlenmesi ön plana çıkmış, ancak kalıpların boyutlarının farklılığı, T dalgasının genlik ve süresinin zamana bağlı olarak değişebilmesi performansta kötü etki yaratmıştır. Bunların yanında deterministik olmayan stokastik yöntemler özellikle yapay sinir ağlar ile birlikte Gauss karışım modeli ile çalıştırılmıştır. Bu yaklaşım özellikle öğrenme aşamasında çok büyük bir kolaylık sağlamış, probleme genellik kazandırmış olmakla birlikte, belirli bir alan bölgesinin işlenmesinden dolayı, özellikle aynı parametre değerlerine sahip birden fazla bölge bulunması durumlarında, sıklıkla hatalı sonuçlara yol açmış. Bu tür sorunların giderilmesi için ekstra işlemler ile performans iyileştirilmesi zorunlu bir hal almıştır[11].

Yapay sinir ağlarının statik yapısına istinaden oluşan bu problemlerden dolayı araştırmacılar geri-dönüşümlü yapay sinir ağı modelleri ile zamana bağlı verilerin işlenmesi için pek çok çalışma yapma gereği duymuşlardır[14]. Bu çalışmada, EKG sinyalinin saptanması zor noktalarından biri olan $\mathrm{T}$ dalgasının sonunun, yani ventriküllerin gevşemesinin son noktasının tespitini yapabilen bir algoritma, dinamik yapıda geri-dönüşümlü yapay sinir ağları kullanılması önerilmiştir. Standart yöntemlerden farklı olarak girilen parametrelerin verileri ile Küme diyagramları metodu kullanılarak veriler düzenlenmiş ve buna bağlı olarak belirli sayıda nöron ve geri-dönüşüm sayısı belirli alanları kapsayacak şekilde eğitime verilmiştir.

\section{MATERYAL VE METOT}

Bu çalışma için seçilen EKG kayıtları T sonu hesaplaması için Geri Dönüşümlü Sinir Ağı'na (GDSA) eğitime verilmiştir ve bu eğitimde elde edilen sonuçlar ile referans sonuçların karşılaştırılması yapılmıştır. T sonu hesaplaması için EKG sinyalleri ilk olarak ön işleme ile sonlu darbe yanıtlı (SDY) filtresinden geçirilmiştir. Algoritmanın çalıştırılabilmesi için GDSA'nın T dalgasını saptaması gerekmektedir. Bu işlem için filtrelenmiş sinyal ile filtrelenmemiş sinyalin $\mathrm{P}$, QRS ve $\mathrm{T}$ dalgası için gösterdiği farklılıklar incelenmiş ve buna bağlı olarak bir verilerin ayrıştırılması gerçekleştirilmiştir.

Geri Dönüşümlü Sinir Ağ’1 eğitimi sonucu bulunan T dalgası Küme Diyagram Modeli ile doğrulanıp T sonu analizi yapılarak referans sonuçlarla karşılaştırılmıştır

Metot dört kısımdan oluşmaktadır: ön işlemler, alan ayrıştırması, GDSA eğitimi ve T dalga sonunun ayrılması. Ön işleme kademesinde EKG sinyalinin özelliklerinin arttırımı ve bu özelliklerin Kümeleme metoduna uygun yapıda oluşması için SDY filtreleme ve normalizasyon kullanılmıştır. İkinci kısımda alan ayrıştırması, yeni oluşturulmuş verileri farklı bölgelerde kurmak ve bu bölgeler sayesinde ayrışma kapasitesi arttırılmıştır. Sonrasında, bölgeler arası ayrışmanın zamana bağlı kalıplar ile sınıflama yapılabilmesi için GDSA eğitilmiştir. Son olarak T dalga sonunun işaretlenmesi için filtrelenmiş veriler ile GDSA çıkışlarının kesişim noktaları kullanılmıştır. Şekil 1 algoritmanın aşamalarını göstermektedir. 


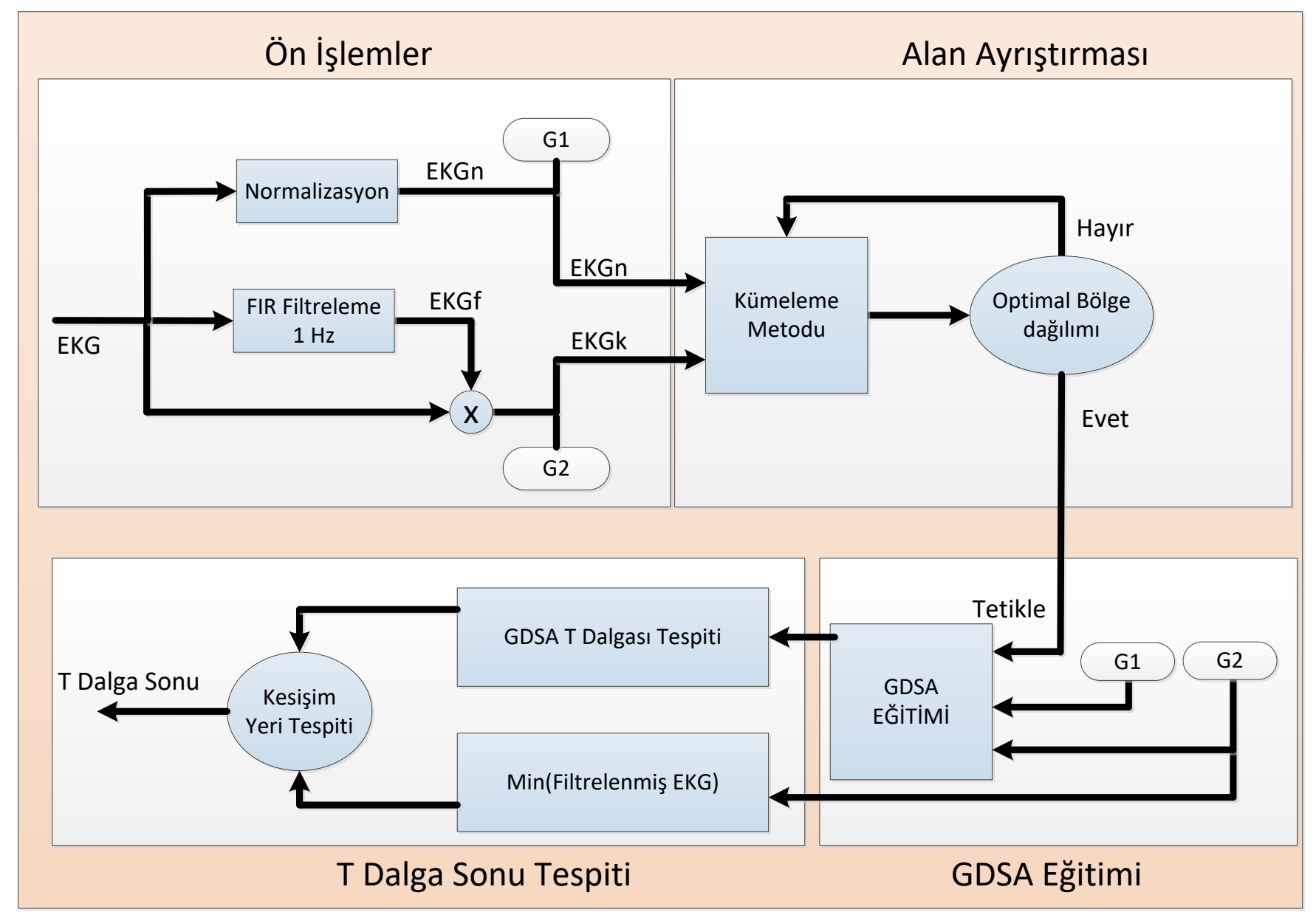

Şekil 1. İşaret akış diyagramı

\section{1. Ön İşlemler}

EKG kayıtları, sıklıkla elektronik ve fizyolojik olarak çeşitli gürültüler barındırmaktadırlar ve buna bağlı olarak anlamlı dalgaların ayrıştırılması zorlaşmaktadır. Geri dönüşümlü sinir ağları, zaman serisi şeklinde verilen bir veri dağılımı üzerinde belirli noktaların eğitilmiş ağın elemanı olup olmadığını sıralı bir biçimde kontrol edebilmektedir ki, bu da bütün sinyal seviyesinin genlik cinsinden aynı seviyede olmasını gerektirmektedir. Bu yüzden EKG sinyallerinin izoelektrik seviyelerinin eşit konuma getirilmesi için $1 \mathrm{~Hz}$ kesme frekans değerine sahip yüksek geçiren sonlu darbe yanıtı (SDY) filtresi uygulanmıştır. $1 \mathrm{~Hz}$ olmasının sebebi farklı atım frekanslarında sinyalinin frekansları değişse bile her farklı kalp atım değerinde bile çeşitli düşük frekans gürültülerinin engellenmesidir. Yapılan işlem sonucunda filtrelenmiş EKG sinyalleri Şekil-2'de gösterilmiştir. 


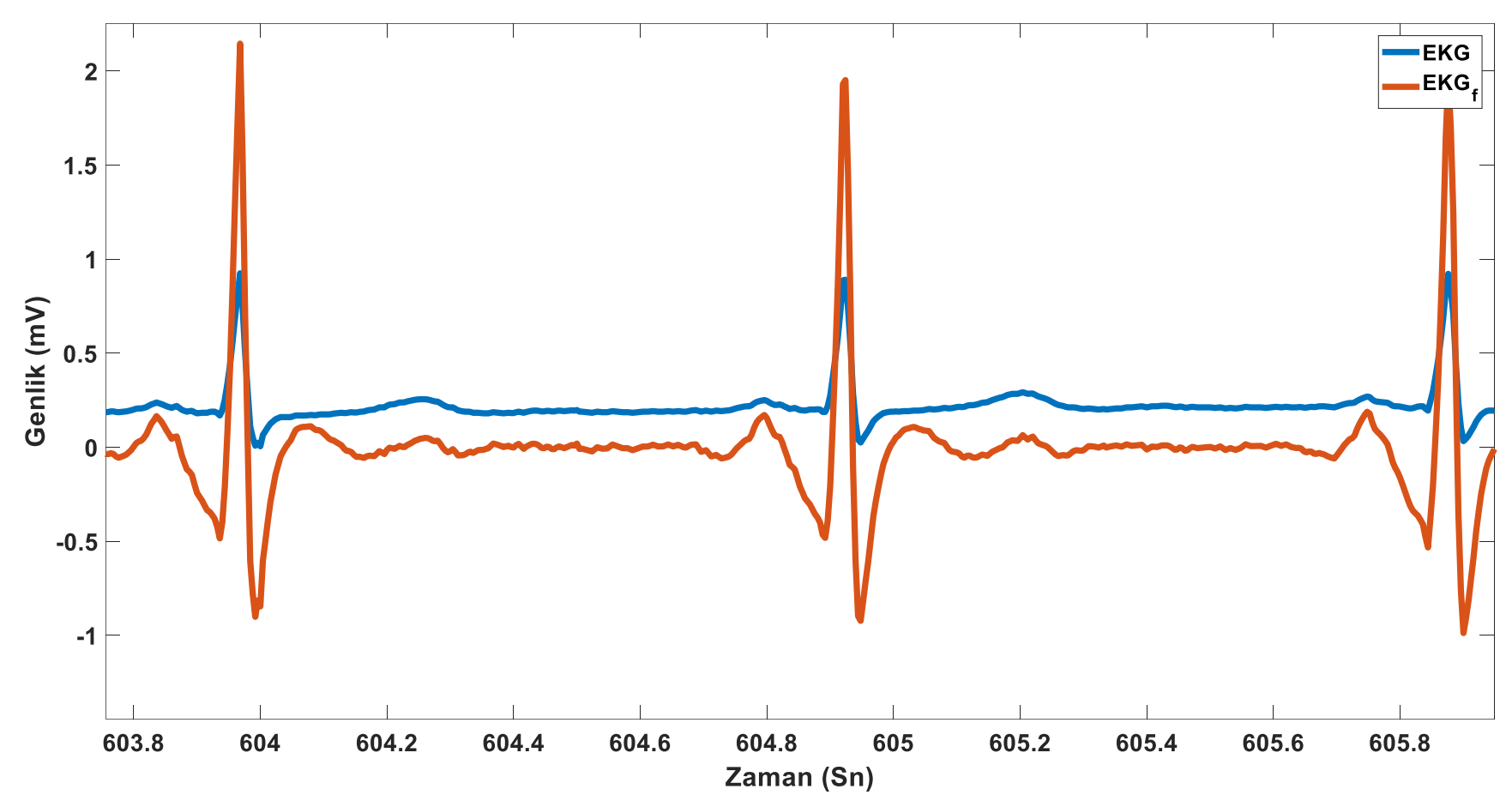

Şekil 2. Gerçek ve filtrelenmiş EKG sinyali

Şekil-2'de yatay eksen zamanı (Sn), düşey eksen ise genlik değerlerini göstermektedir. Kırmızı çizgi ile gösterilen sinyal SYD ile filtrelenmiş EKG’yi, mavi çizgi ile gösterilen sinyal ise normal EKG sinyalini göstermektedir. Şekil incelendiğinde T dalgasının sonu filtrelenmiş sinyalde açıkça maksimum-minimum noktalardan elde edilebilmektedir. Laguna vd bu ilişkiyi yüksek performans ile sinyaller üzerinde uygulayarak göstermiştir. Önerilen algoritmada ön işlenmiş sinyallerin yapay sinir ağları ile değişik gürültü ve hastalık türlerinde de ayrılması hedeflenmektedir [7].

\subsection{Geri Dönüşümlü Sinir Ăğı Modeli}

Geri dönüşümlü sinir ağı, ileri beslemeli sinir ağlarının aksine sahip olduğu nöronlarının birbiri içerisinde de etkileşime girmesine izin vermektedir. Bu özelliğinden dolayı sinyaller sadece tek bir giriş-çıkış için değil, verilen geri dönüşüm sayısına göre sıralı biçimde bir çıkış oluşturur [15]. Böylece verilerin dinamik zamansal davranışlarını taklit etmeyi ve bu davranışların eğitimi ile farklı sinyaller üzerinde tanıma işlemlerini gerçekleştirebilecek bir mekanizmaya sahip olurlar. Bu çalışma da farklı türdeki T dalgalarının kalıplarının öğrenilmesi ve bu değişen kalıplara göre benzer dağılımdaki gözle ayırt edilebilen sinyallerin ayrıştırılmasında kullanılmıştır. Ancak geri dönüşümlü ağların efektif biçimde hedeflenen ayrıştırma ve kümelemeyi yapabilmesi için öncelikle verilerin ön işleme ile uygun formda sunulması gerekmektedir.

\subsection{Küme Diyagramları ile Ayrışım İşlemi}

Küme diyagramları, verilerin karşılıkları olarak belirli bir düzlemdeki dağılımını göstermektedir. Bunun içinde dağılımların ayrıştırılması ve efektif bir biçimde Geri Dönüşümlü Sinir Ağları (GDSA)'nın çalıştırılmasına zemin oluşturmaktadır. Çünkü ileri beslemeli sinir ağ modeli lineer olarak ayrılabilen veriler üzerinde yüksek performansta çalıştırılabilmektedir. Ĕğer lineer olarak ayrılamayan veriler bulunursa geri dönüşümlü sinir ağlarının kullanımı önem kazanmaktadır, ancak bu durum ise verilerin belirli bir düzlem veya çizgi üzerinde toplanması gerekmektedir. Normal olarak, filtrelenmiş ve filtrelenmemiş EKG kayıtlarının referans P,QRS ve T dalgaları için dağılımı Şekil 3'de verilmiştir. 


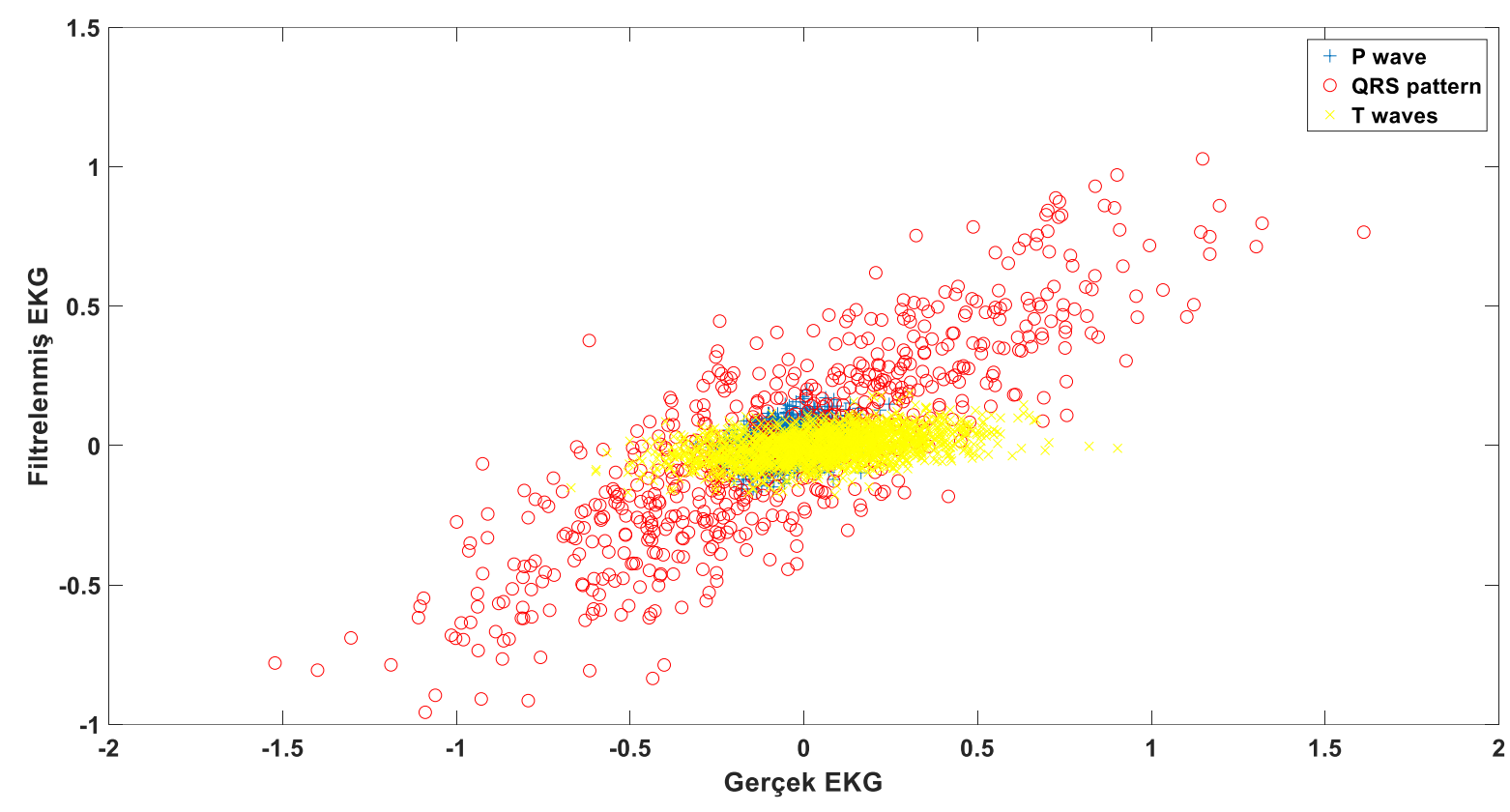

Şekil 3. Filtrelenmiş ve gerçek EKG dağılımı

Şekil 3'de yatay eksen gerçek EKG, düş̧ey eksen ise filtrelenmiş EKG değerlerini göstermektedir. Toplam olarak 3 adet temel dalgacık türümüz (P, QRS, T) grafikte zaman sırasına göre karşılıklı olarak genlik değerleri türünden çizdirilmiştir. Her EKG değeri, kendisine karşılık gelen filtrelenmiş EKG değeri ile grafik alanı üzerinde gösterilmiştir. Grafik incelendiğinde $\mathrm{P}, \mathrm{QRS}$ ve $\mathrm{T}$ dalgalarının iç içe geçtiği gözlemlenmektedir. Bu yüzden kovaryans matrislerine göre işlemler alan olarak ayrılamayacak bir formda bulunmaktadır. Kovaryans dağılımın bir göstergesi olarak sinyallerin ayrılıp ayrılamayacağını gösteren matematiksel bir öğe olarak bu çalışmada kullanılmıştır. Eğer kovaryans matrisleri gibi bir gösterimle grafikleştirme yapılmazsa, sinir ağının performansı ve ayrıca önişleme uygulanacak adımların belirlenmesi zorlaşacaktır. Bu yüzden, GDSA'nın aktif bir biçimde çalıştırılabilmesi için belirli bir alanda değil, doğrultulu bir çizgideki sinyallerin işlenmesi daha uygun olmaktadır. Bu yüzden kullanılan sinyaller denklem 1’e göre yeniden düzenlenmiştir.

$G V=\left\{E K G_{k}, E K G_{n}\right\}$

Burada $G V$ giriş vektörünü, $E C G_{k}=f E C G * E C G$ ise karma EKG sinyalini $f E C G$ filtrelenmiş EKG sinyalini ve $E C G_{n}$ normalize edilmiş EKG sinyalini göstermektedir. Normalizasyon işlemi denklem 2’ye göre yapılmıştır.

$E K G_{n}=\frac{E K G-\min (E K G)}{S}$

Burada $S=\max (E K G)-\min (E K G)$ 'dir ki bu da sınır değerlerini göstermektedir. Normalizasyonu \{alt, üst $\}$ arasına getirmek için

$E K G_{n}=(E K G *(\ddot{s} s t-a l t))+$ alt

alt ve üst değerler sırası ile -1 ve +1 olarak seçilmiştir.

Bu sinyallerin dağılımlarının incelemesi, Şekil 4’te gösterilen dağılım diyagramları ile gösterilmiştir. 
M. Işscan, A. Yeşildirek

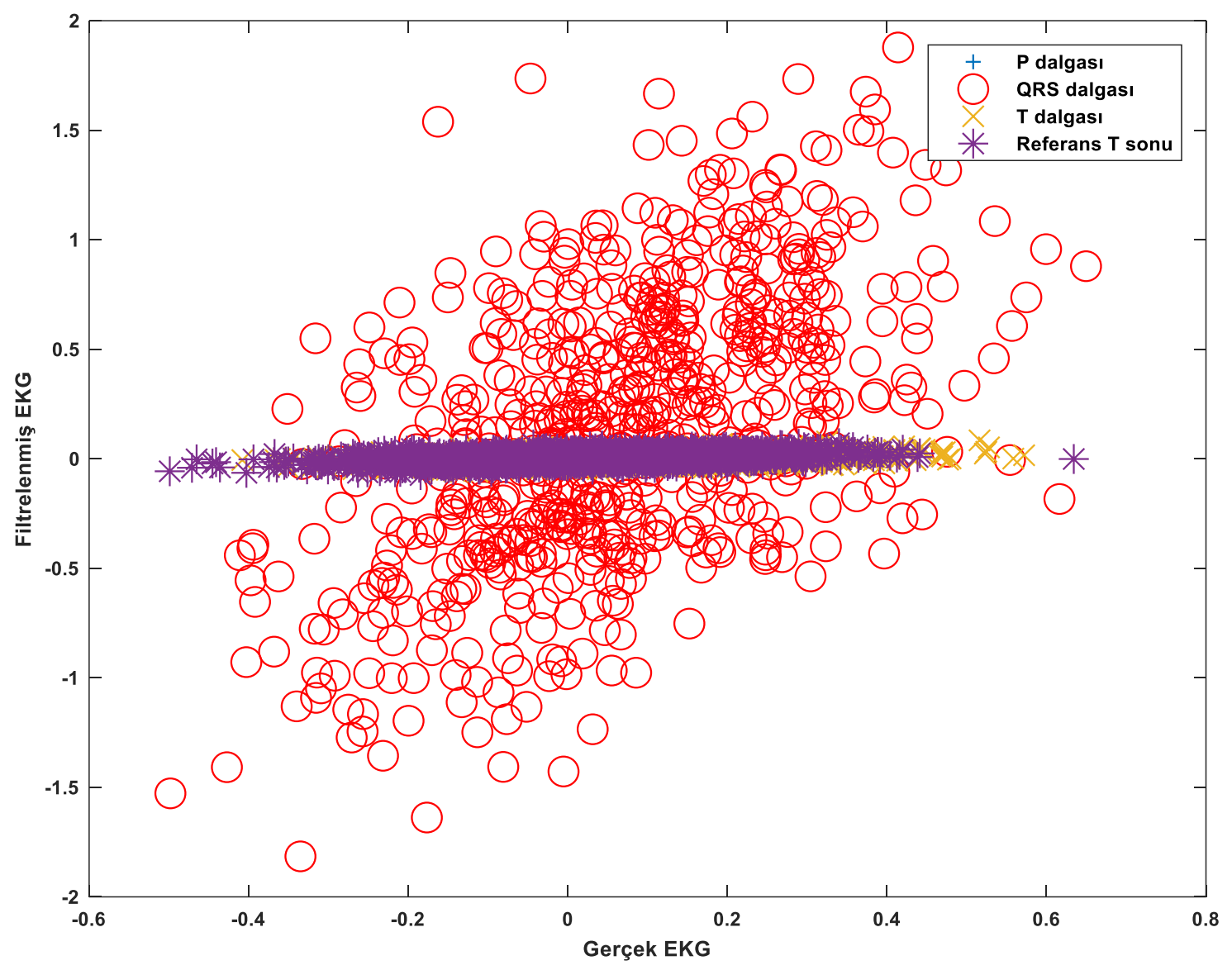

Şekil 4. İşlenmiş EKG diyagramı

Şekil 4'te gösterilen veri dağılımında yatay eksen denklem 1'de birinci sinyali, düşey eksen ise ikinci sinyali göstermektedir. Ayrıca T dalgasının sonunu oluşturan referans sinyallerin hepsinin dağılımı da grafiğe eklenmiştir. Buna göre hem $\mathrm{T}$ dalgası hem de son noktaları aynı bölgelerde bulunmuştur ki bu geri dönüşümlü sinir ağları için uygun bir formda olduğunu bize kanıtlamaktadır

\subsection{T Dalgası Eğitimi}

Normalize edilmiş EKG sinyali ve karma EKG sinyali yapay sinir ağına verilmiştir. Eğitim fonksiyonu olarak Bayes düzenlilik geri yayılımı kullanılmıştır. Bu metot, fonksiyonu belli olmayan EKG sinyalinin verilerini toplamakta ve bu veriler ile nesnel bir fonksiyon oluşturarak doğru bir dağılım oluşturmayı amaçlamaktadır.

Ağa girilen ilk girdi denklem 1'de gösterilen filtrelenmemiş EKG sinyallerinden oluşan bir matristir. İkinci girdi olan Karma girdi ise ağın T dalgasını tanıması için P, QRS ve T dalgalarının farklı davranışlar sergilediği filtrelenmiş sinyal ile filtrelenmemiş sinyalin çarpımından oluşturulmuştur. Bu girdide P dalgası çok küçülürken QRS dalgası ilk girdinin pozitif değer aldığı kısımlarda negatif değere ulaşır. T dalgası ise pozitif değerde kalmıştır. Dalgaların farklı özelliklerinin tanımlanmasıyla T dalgası tespitinin ispati için Küme Diyagramı Metodu uygulanmıştır.

\subsection{T Dalgası Sonu Testipi}

Sunulan algoritma toplam 4 aşamadan oluşmaktadır. Bunlar sırası ile GDSA'nın T dalgasını tanıması, tanınan T dalgalarının belirli bir eşik değeri ile düzgünleştirilmesi, düzgünleştirilmiş $\mathrm{T}$ dalga işaretlerinin son noktasının bulunması ve bu bulunan işaret ile filtrelenmiş EKG sinyalinin kesişim noktasının tespitidir. Şekil-5 algoritmanın bir EKG sinyali üzerindeki işlem aşamalarını göstermektedir. 

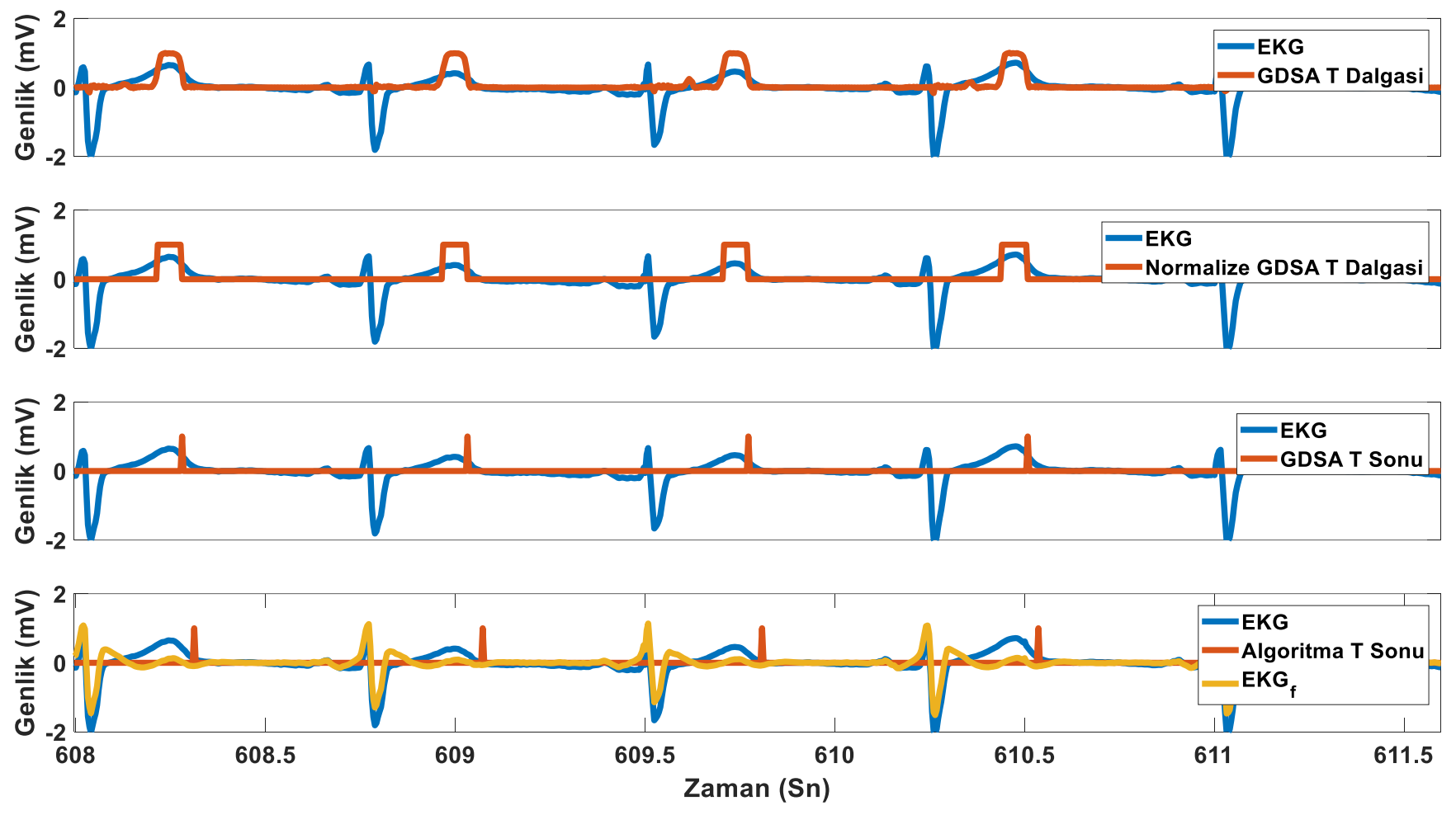

Şekil 5. Algoritmanın çalışma aşamaları

Eğitilen ağın işaretlediği T dalgalarının bitişinin bulunması aşağıdaki atama ile ifade edilmiştir.

$$
T D(i)<--\left\{\begin{array}{l}
1, T D(i) \geq 0.5 \\
0, T D(i)<0.5
\end{array}\right.
$$

Burada TD T dalgasını göstermekte ve içindeki değerler tekrardan 1 olarak işaretlenmektedir. GDSA'nın T dalgası olarak saptama yaptığı kısımda işaretleme yapılarak T bitiminin bulunması kolaylaştırılmıştır.

$$
k=\left\{\begin{array}{lr}
i d x=i d x+i, T D(i)=1 \\
0, & T D(i)<>1
\end{array}\right.
$$

Burada k T dalgasının son konumunu, idx ise işaretlemeler yapılana kadar olan artım işlemini göstermektedir. İşaretlenmiş kısımda dalganın sonunu işaretlemek için T dalgasının 1 olduğu andan itibaren matrisin o andaki indeksine ekleme yapılır ve dalganın 1 olmadığı konuma kadar saydırma yapılır. T dalgasının 1 olmadığı andaki matrisin indeks değeri $\mathrm{T}$ bitiminin konumu olarak işaretlenir.

$$
T B(k)=1 \rightarrow T B(H K)=0
$$

Denklem (6)’te TB T dalgasının geri-dönüşümlü ağdan gelen bitişini göstermektedir. Bundan sonra belirli bir çalışma aralığı belirlenip T dalgasının son noktası bu çalışma aralığında aranır. Şekil 6 çalışma aralığını göstermektedir. 


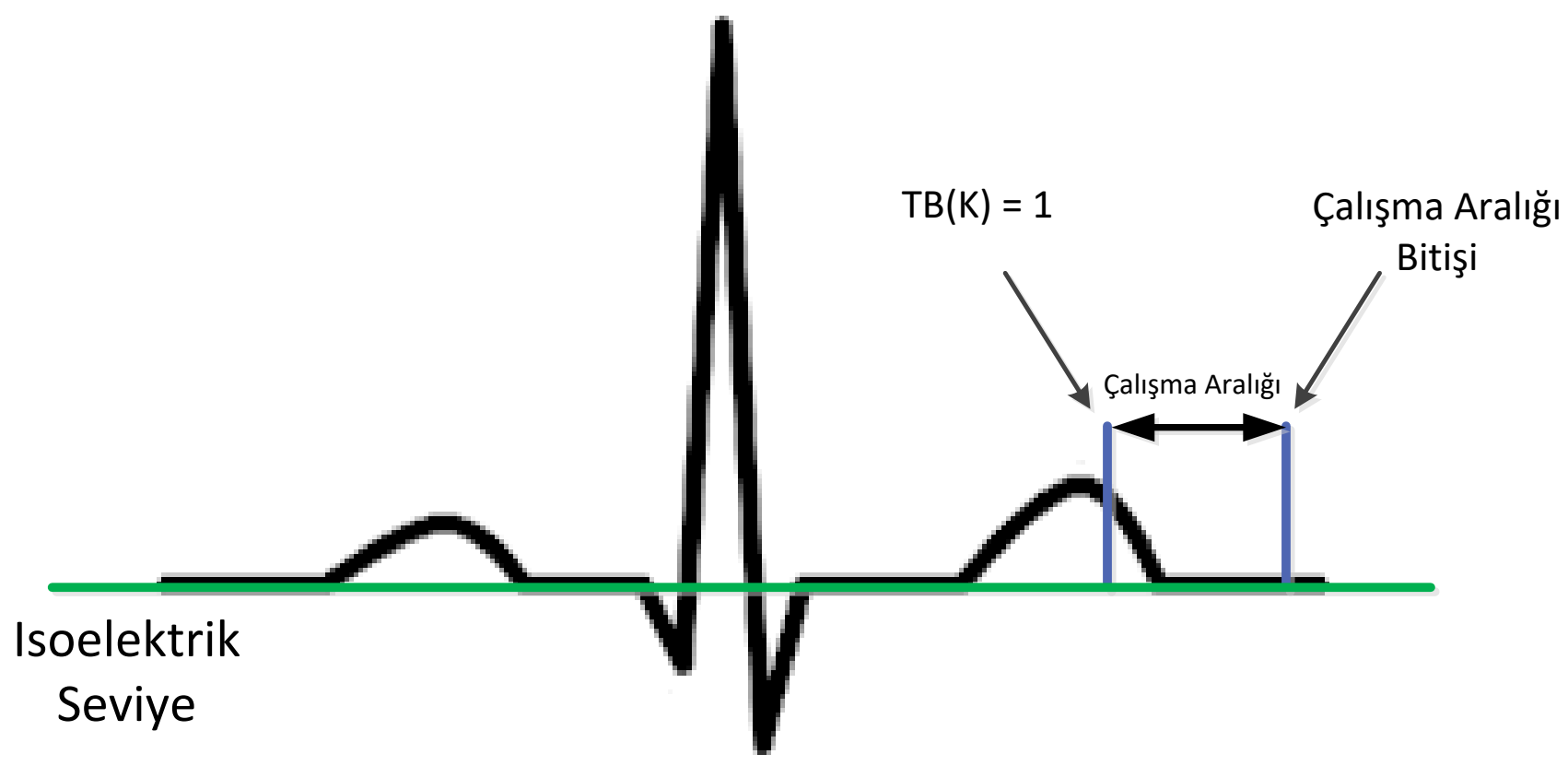

Şekil 6. Çalışma Aralığının işleyiş mekanizması

Çalışma aralığı sunulan algoritma için 15 veri $(15 \times 0.004=60$ milisaniye) olarak seçilmiştir ki bu da fizyolojik limitlerin içindedir. Bundan sonraki etapta minimum değer ile karşılaştırma yapılır. $\mathrm{T}$ bitiminin bulunan konum değeri 1 olarak işaretlenir. Diğer konum değerleri için işaretleme 0 olarak yapılır.

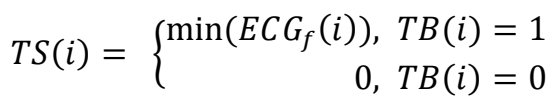

Burada TS T dalgası sonunu göstermektedir. Denklem 4'de bahsedilen T bitim noktası, T dalgasının sadece ham EKG verisi ile bulunduğu için $\mathrm{T}$ dalgasının gerçek sonucunu yansıtmamaktadır. T dalgasının sonunu bulmak için filtrelenmiş EKG sinyalinde $\mathrm{T}$ bitiminden sonra Denklem 5 uyarınca minimum nokta aranır ve filtrelenmiş EKG dalgasının bilgisi ile gerçek T dalga sonu bulunur.

Bulunan minimum nokta $\mathrm{T}$ dalgasının sonudur. Kümeleme diyagramlarında da gösterildiği gibi $\mathrm{T}$ dalgasının sonları, $\mathrm{T}$ dalgasının minimum ve sıfır noktalarına doğru bir eğilim göstermektedir. Karma yerine filtrelenmiş EKG sinyalinin kullanılmasının nedeni SDY filtresi uygulanmış ECG sinyalinin izoelektrik seviyeye inerken ya da o seviyeden uzaklaşırken ani bir dalgalanma oluşturması ve bu dalgalanmanın minimum olduğu noktanın, T sonunu doğru olarak göstermesidir.

EKG Sinyalindeki düşük frekanslı gürültüler azaltılınca o noktalardaki genlikler de azaltılmış olur ve bundan dolayı $\mathrm{P}$ ve $\mathrm{T}$ dalgalarının izoelektrik seviyelerinde dalgalanmalar oluşmaktadır. $\mathrm{T}$ dalgasının bitişinden itibaren dalgalanma oluşturan filtrelenmiş EKG sinyalinin minimum olan noktası aranmaktadır ki bunun sebebi filtrelenmiş ve filtrelenmemiş EKG sinyalleri arasında bir faz farkı olmasıdır. Bu yüzden $\mathrm{T}$ sonu olarak izoelektrik seviye yerine minimum nokta seçilmekte, ve sonuç iyileştirilmektedir.

\section{BULGULAR VE TARTIŞMA}

PHYSIONET veri bankasının QT veri tabanından seçilen 15 EKG sinyali ile eğitilmiş ağ ve buradan elde edilen sonuçlar, eğitilmiş ağ $\mathrm{T}$ sonu ve referans $\mathrm{T}$ sonları karşılaştırılarak bulunmuştur. Karşılaştırma ortalama hata bulunarak yapılmıştır. Kayıtlar $250 \mathrm{~Hz}$ örnekleme frekansına sahiptir. Toplam 295 atım test ve eğitim için kullanılmıştır. Bu atımlardan 55’i eğitim için kullanılmıştır. 55'i Eğitim verileri fizyolojik olarak stabil atım oranı (RR)'na sahip atımlardan elde edilmiştir. Standart olarak her kayıttan 3 anlamlı atım seçilmiş, ancak bazı kayıtlardan fizyolojik durumları gösteren 5'er tane farklı atım seçilmiştir. Ayrıca algoritmanın performansının başka kalıplar üzerinde de test edilmesi için toplam 420 kayıt daha test edilmiştir. Örnek olarak Şekil 7'de önemli noktaların işaretlenmesi verilmiştir. 


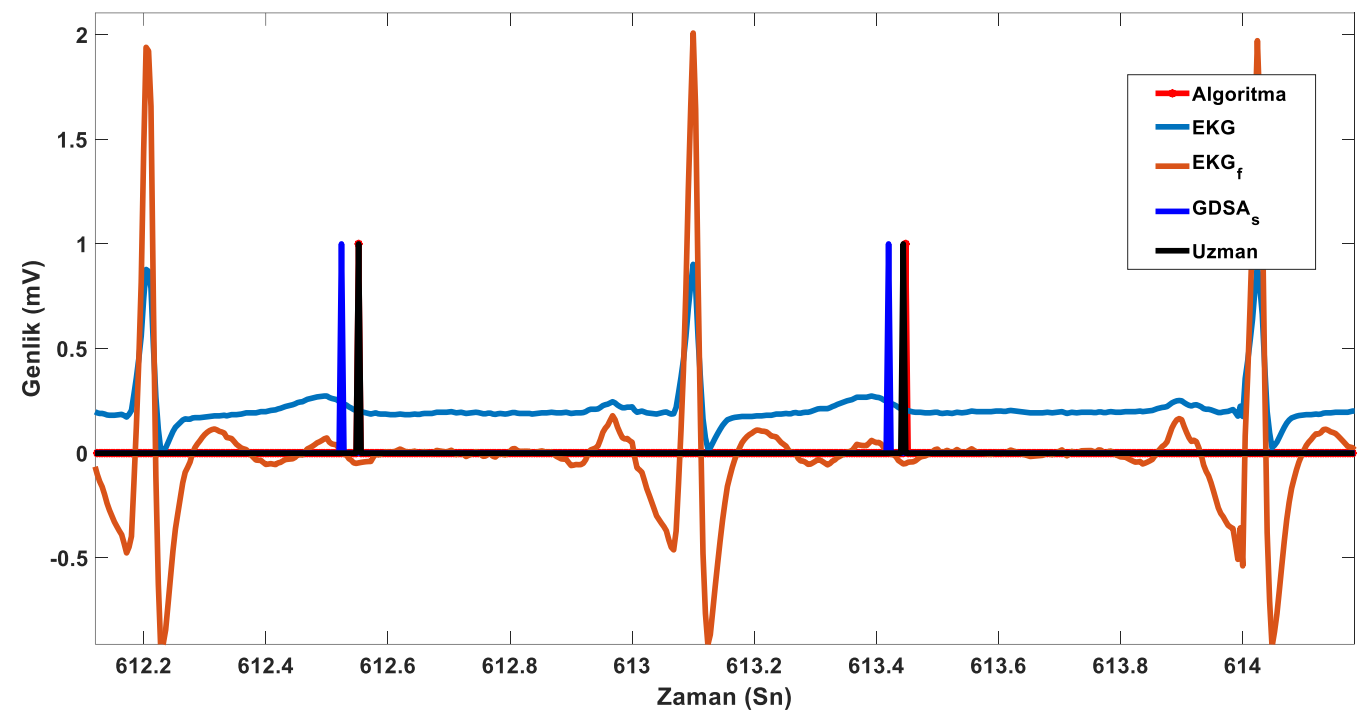

Şekil 7. EKG Dalgalarının İşaretlenmesi

Dikey eksen sinyalin voltaj değerlerini, yatay eksen de zaman (Sn) değerini göstermektedir. Mavi renkli $1 \mathrm{mV}$ değeri ile işaretlenmiş olan noktalar eğitilmiş ağdan gelen T bitimi noktalarını göstermektedir, ki bunlar GDSA'nın çıkışı olarak grafikte gösterilmiştir. T bitimi noktasından 15 örnek penceresi boyunca minimum nokta aranır. Bulunan minimum nokta yeşil renkli sinyal ile belirtilen $\mathrm{T}$ dalgasının sonu olarak işaretlenmiştir. Siyah renkle gösterilen noktalar ise uzmanların işaretlediği $\mathrm{T}$ dalga sonlarını göstermektedir. Genel ortalama da sunulan algoritmanın performansı Uzmana göre değerlendirilip Tablo 1'de verilmiştir.

Tablo 1. Mutlak hata sonuçları

\begin{tabular}{|c|c|c|c|}
\hline \multirow[b]{2}{*}{$\begin{array}{l}\text { Kaylt } \\
\text { İsmi }\end{array}$} & \multicolumn{3}{|c|}{ Test Sonuçları } \\
\hline & Atım Sayısı & $\begin{array}{l}\text { Ortalama } \\
\text { Hata (ms) }\end{array}$ & $\begin{array}{c}\text { Standart } \\
\text { Sapma } \\
(\mathrm{ms})\end{array}$ \\
\hline $\begin{array}{l}\text { sel140 } \\
46\end{array}$ & 27 & 6.37 & 7.95 \\
\hline $\begin{array}{l}\text { sel162 } \\
65\end{array}$ & 30 & 15.20 & 9.22 \\
\hline $\begin{array}{l}\text { sel162 } \\
72\end{array}$ & 26 & 10.46 & 5.81 \\
\hline $\begin{array}{l}\text { sel162 } \\
73\end{array}$ & 25 & 10.88 & 5.58 \\
\hline $\begin{array}{l}\text { sel164 } \\
20\end{array}$ & 25 & 11.20 & 6.47 \\
\hline $\begin{array}{l}\text { sel164 } \\
83\end{array}$ & 28 & 12.71 & 6.86 \\
\hline $\begin{array}{l}\text { sel165 } \\
39\end{array}$ & 27 & 12.88 & 7.47 \\
\hline $\begin{array}{l}\text { sel167 } \\
73\end{array}$ & 25 & 9.12 & 4.74 \\
\hline $\begin{array}{l}\text { sel167 } \\
86\end{array}$ & 28 & 10.71 & 6.44 \\
\hline $\begin{array}{l}\text { sel167 } \\
95\end{array}$ & 28 & 11.71 & 4.15 \\
\hline $\begin{array}{l}\text { sel174 } \\
53\end{array}$ & 26 & 11.53 & 3.15 \\
\hline Toplam & 295 & 11.16 & 6.16 \\
\hline
\end{tabular}


M. Işscan, A. Yeşildirek

Tablo-1 de referans veri bölümünde bulunan sonuçlar eğitilmiş ă̆ ile bulunan $T$ sonları ile referans değerlerinin farkı alınarak elde edilmiştir. Yapılan test sonucu bulunan T sonu değerlerinin referans değerlerinden ortalama 11.16 milisaniye ve 6.16 milisaniye standart sapma değeri ile işlemler gerçekleştirilebilmiştir.

Mutlak standart hatanın dışında verilen sonuçlara göre bazen algoritmanın karakteristiği ile alakalı olarak mutlak olmayan ve işaretlerin geride mi yoksa ileride mi kaldığını araştırmamıza yarayan bir yöntemde kullanılmaktadır. Buna dair sonuçlar Tablo 2'de gösterilmiştir.

Tablo 2. Mutlak olmayan Hata Sonuçları

\begin{tabular}{|c|c|c|c|}
\hline \multirow[b]{2}{*}{$\begin{array}{l}\text { Kayıt } \\
\text { İsmi }\end{array}$} & \multicolumn{3}{|c|}{ Test Sonuçları } \\
\hline & Atım Sayısı & $\begin{array}{l}\text { Ortalama } \\
\text { Hata (ms) }\end{array}$ & $\begin{array}{c}\text { Standart } \\
\text { Sapma } \\
(\mathrm{ms})\end{array}$ \\
\hline $\begin{array}{l}\text { sel140 } \\
46\end{array}$ & 27 & -4.7 & 6.25 \\
\hline $\begin{array}{l}\text { sel162 } \\
65\end{array}$ & 30 & -2.93 & 5.27 \\
\hline $\begin{array}{l}\text { sel162 } \\
72\end{array}$ & 26 & -0.93 & 6.43 \\
\hline $\begin{array}{l}\text { sel162 } \\
73\end{array}$ & 25 & 6.08 & 6.03 \\
\hline $\begin{array}{l}\text { sel164 } \\
20\end{array}$ & 25 & -6.72 & 6.85 \\
\hline $\begin{array}{l}\text { sel164 } \\
83\end{array}$ & 28 & -12.1 & 6.95 \\
\hline $\begin{array}{l}\text { sel165 } \\
39\end{array}$ & 27 & -4.59 & 8.17 \\
\hline $\begin{array}{l}\text { sel167 } \\
73\end{array}$ & 25 & -3.36 & 5.21 \\
\hline $\begin{array}{l}\text { sel167 } \\
86\end{array}$ & 28 & -7.57 & 6.79 \\
\hline $\begin{array}{l}\text { sel167 } \\
95\end{array}$ & 28 & -15.1 & 8.24 \\
\hline $\begin{array}{l}\text { sel174 } \\
53\end{array}$ & 26 & 0.153 & 6.86 \\
\hline Toplam & 295 & -4.70 & 6.64 \\
\hline
\end{tabular}

Mutlak olmayan sonuçlar genellikle algoritmanın işaretleme noktasının nerede olduğuna dair bilgiler içermektedir ve bu değerler ortalama hata ve bu hatanın etrafında ne kadar uzaklıkta bir hata oluştuğunu göstermektedir. Yapılan test sonuçlarına göre toplam 295 atımda $-5.87 \pm 2.83$ bir hata değeri ile algoritma çalıştırılabilmiştir. Ortalama hata değerleri çoğunlukla negatif çıkmıştır, çünkü algoritmanın GDSA sonuçları uzmanlar tarafından işaretlenmiş $\mathrm{T}$ dalgasının sonundan geride kalmıştır. Genellikle frekansa bağlı bu değişim, filtrelenmiş EKG sinyalinin minimum noktası ile alakalıdır.

Diğer yandan T dalgasının pozitif olduğu toplam 20 kayıt daha PHYSIONET/QT Veritabanından seçilmiş ve Tablo 3'teki sonuçlara ulaşılmıştır.

Tablo 3. Mutlak olmayan Hata Sonuçları - Farklı Kayıtlar

\begin{tabular}{lccc}
\hline $\begin{array}{l}\text { Kayıt } \\
\text { İsmi }\end{array}$ & Atım Sayısı & $\begin{array}{c}\text { Test Sonuçları } \\
\text { Ortalama } \\
\text { Hata }\end{array}$ & $\begin{array}{c}\text { Standart } \\
\text { Sapma }\end{array}$ \\
\hline 20 Kayıt & 421 & -6.4 & 17.22 \\
\hline
\end{tabular}

Tablo 3'teki sonuçlar algoritmanın eğitilmemiş verileri değerlendirirken bile yüksek performansa ulaşabildiğini göstermektedir. T dalgasının sonunun bulunması için ve klinik olarak anlamlı olabilmesi için gerekli standart limitler, doktorlar tarafından $15 \pm 30.6$ milisaniye olarak belirlenmiştir [18]. Çalışmanın sonuçlarına göre bu sunulan algoritma bu performansı sağlayabilmiştir. 
Bu çalışmada geri-dönüşümlü sinir ağları tabanında EKG’nin önemli dalgalarından biri olan ve kalpte gevşemeyi gösteren $\mathrm{T}$ dalgasının tespiti yapılmış ve buna istinaden kümeleme diyagramının da yardımı ile $\mathrm{T}$ dalgasının son noktasının işaretlenmesi gerçekleştirilmiştir.

Öncelikle sunulan çalışmada kullanılan algoritmada standart olarak elle işaretlenen 15 kayıt seçilmiş ve bunlardan uygun olmayan kayıtlar elenmiştir (4 kayıt). Uygun olmayan kayıtların temel problemleri iki-fazlı T dalgasına sahip olma, ST depresyona uğrama ve bazısında $\mathrm{P}$ dalgasının $\mathrm{T}$ dalgasının içine girilmesi sayılabilir. Algoritma sadece $\mathrm{T}$ dalgasının pozitif olduğu yerlerde işletilebilmektedir, çünkü eğitime verilen bütün kalıpların hepsi bu sırayı takip edecek şekilde tasarlanmıştır. Bunların dışında uygun kalıplarla alınan ekstra 20 kayıt ile de performansı ölçülmüştür. Testler mutlak olan ve olmayan koşullarda incelenmiştir, çünkü gerçek algoritma performansı standartlarda mutlak olan koşullar için belirtilmiştir [16]. Mutlak olan sonuçlara göre sunulan algoritma seçilen kayıtlar üzerinde standart değerlerin içinde $\mathrm{T}$ dalgasının son noktasını saptayabilmiştir. Ancak T dalgasının kalıp şekline bağlı olması bütün veri tabanı üzerinde test yapmaya imkan vermemektedir. Sunulan algoritma için çıkarılan 4 kayıt (sel14157, sel14172, sel15814 ve sel 17152) ve performans sonuçları aşağıdaki gibi incelenebilmektedir.

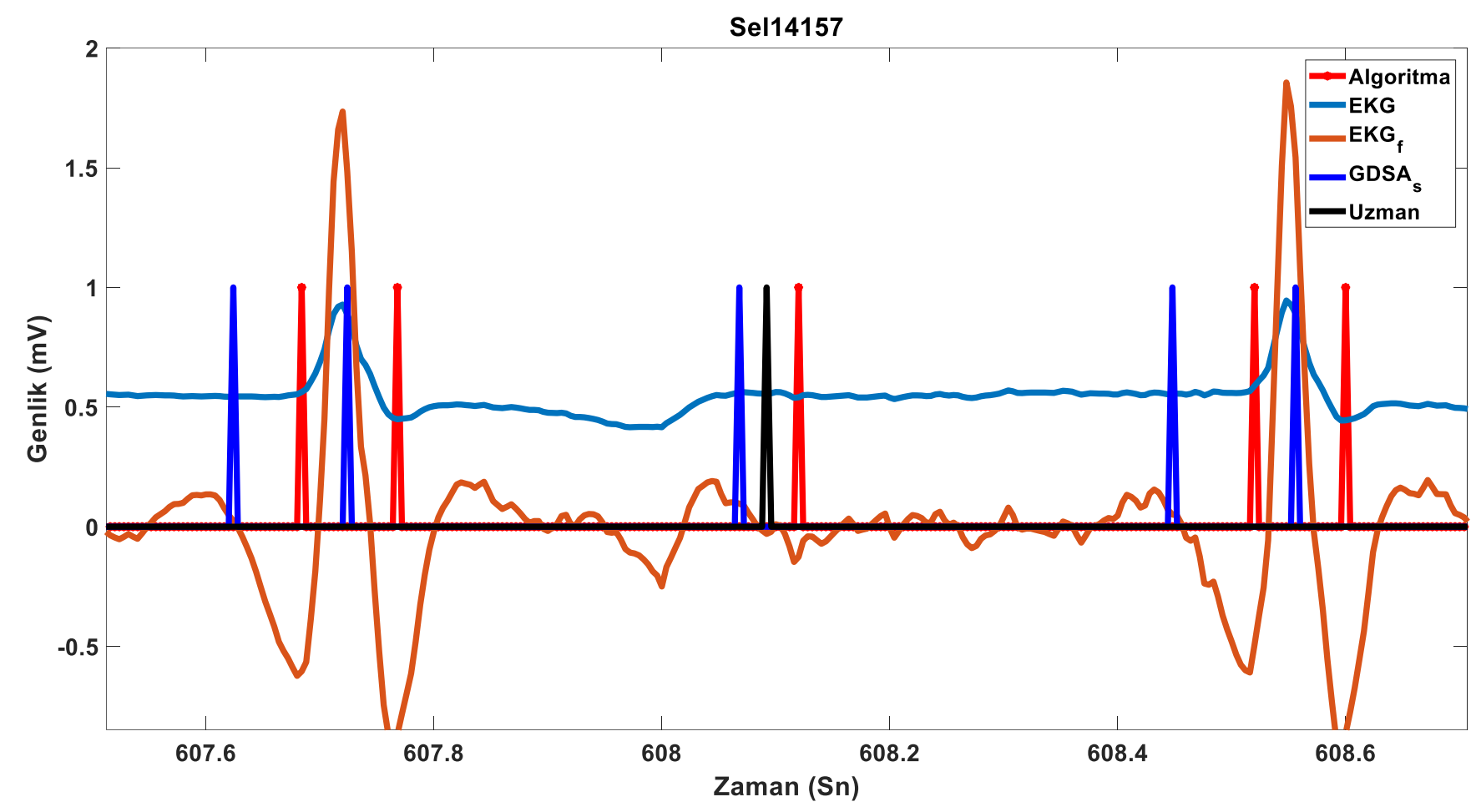

Şekil 8. ST depresyona sahip bir EKG grafiği (Sel14157 Kaydı)

Sel14157 kaydı, genel yapısı itibari ile ST depresyona sahip bir EKG grafiği çizmektedir. Bundan dolayı da T dalgasının işaretlenmesinde kullanılan yöntemlere bakacak olursak T dalgası tam olarak oluşmadığından dolayı depresyonun bitişinde ki tepe noktası T dalgası olarak bulunmuştur. Bundan dolayı işaret hep uzmanın işaretlediğinden ileride gösterilmiş ve hata oranı artmıştır. Ayrıca ST depresyondan dolayı QRS kompleksteki eğim değerlerine bağlı olarak GDSA yanlış sonuçlar üretmiştir. Romero ve diğerleri [17] miyokard enfarktüsüne bağlı olarak oluşan bu durumu çalışmış, ve oluşan ST depresyonun QRS kompleksi bozduğunu göstermiştir. Bütün bu sebeplerden dolayı QRS kompleks sanki T dalgası gibi değerlendirilmiş ve bu değerlendirmelerle yanlış olarak T dalgası sonu bulunmuştur. 


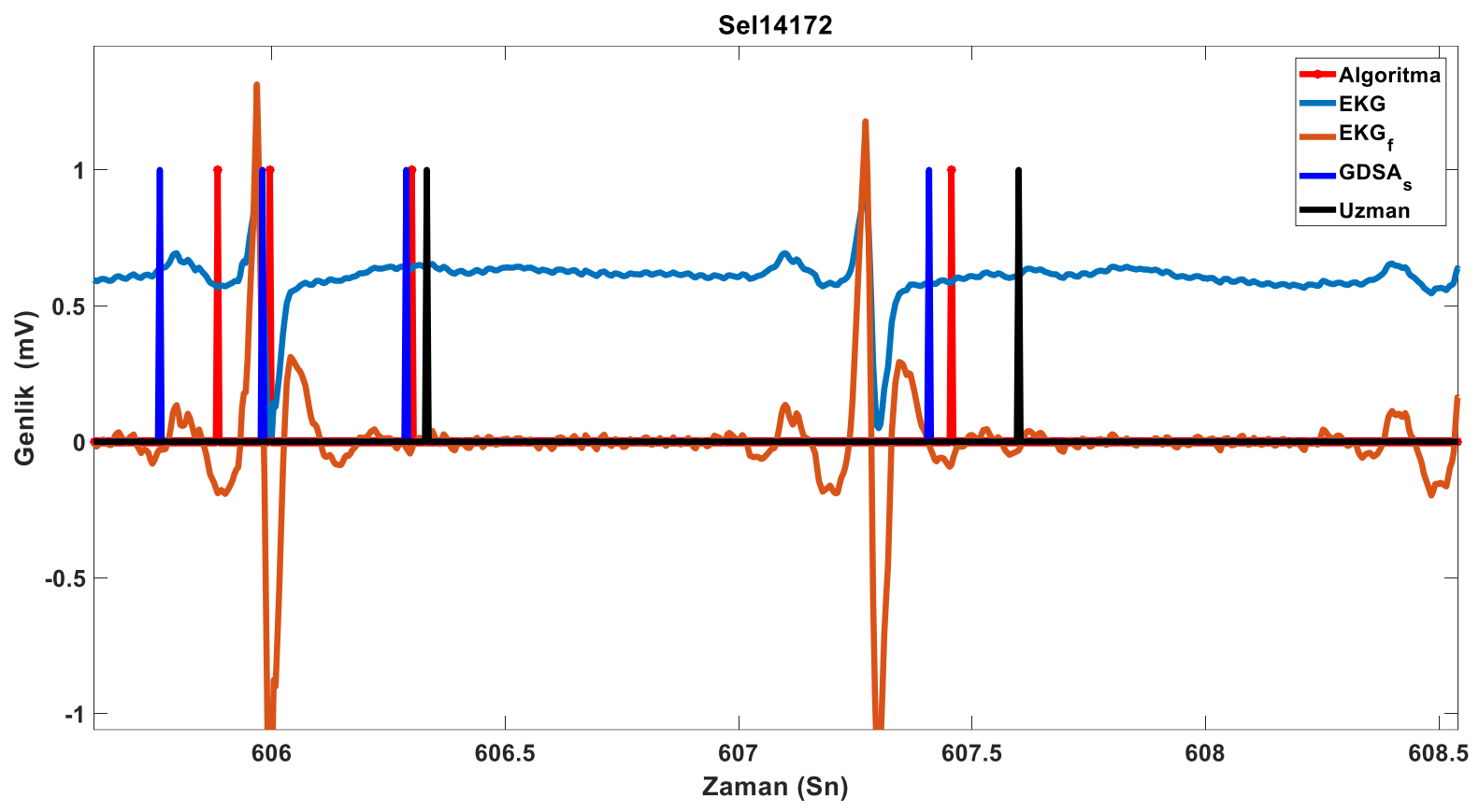

Şekil 9. İki-fazlı T dalgası (Sel14172 Kaydı)

Sel14172 kaydı iki-fazlı T dalgasına karşılık gelmektedir, ki gevşemeye bağlı oluşan problem burada da QRS komplekse etki etmektedir. Ayrıca T dalgasının son noktasının bulunan değerleri T dalgasının sonunu değil, tam arasını göstermektedir. $\mathrm{Bu}$ yüzden verilen dalga formu ve algoritmanın minimum noktayı işaretlemesinden dolayı $\mathrm{T}$ dalgasının sonu ne yazık ki bulunamamıştır.

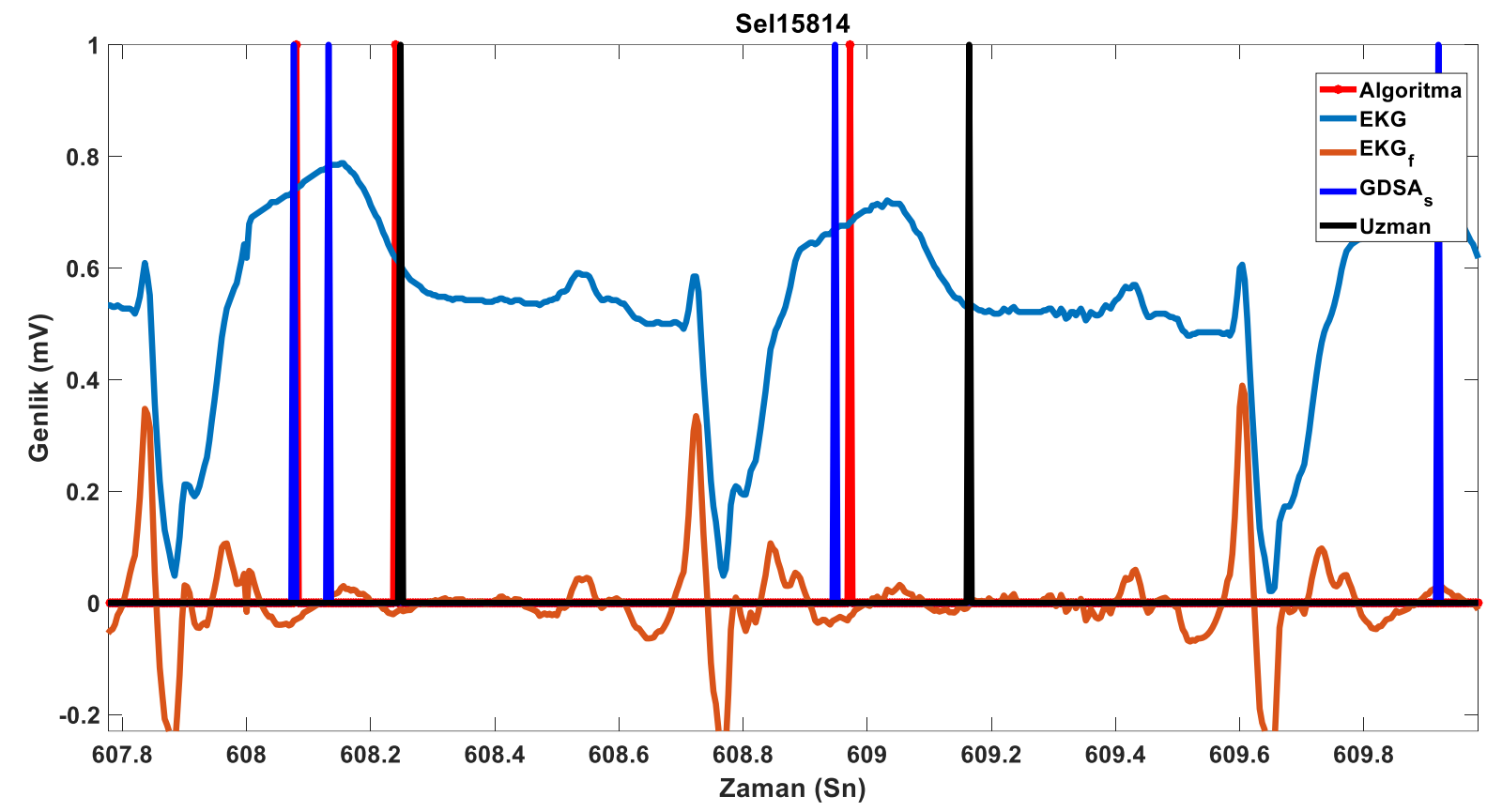

Şekil 10. Ani kardiyak krizi (Sel15814 Kayd1) 


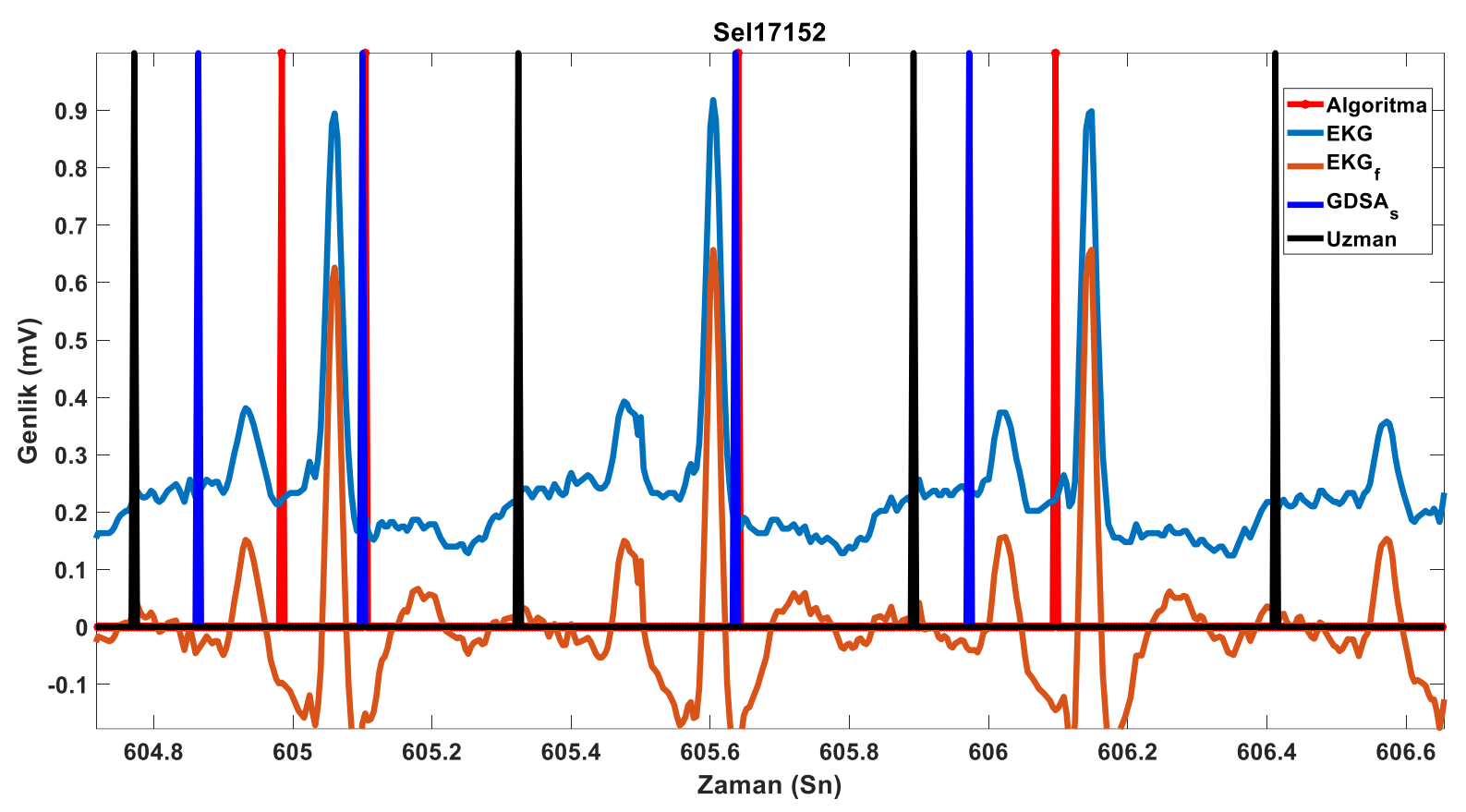

Şekil 11. Düz ST depresyonu (Sel17152 Kaydı)

Sunulan algoritmanın kabiliyeti üzerine konuşacak olursak, algoritma ön bir işlem gerektirmektedir ve tam-otomatik olarak çalıştırılamamaktadır. Eğitim yapılması ve olabildiğince çok T dalgası kalıbı ile ve karşıtı ile beslenmesi gerekmektedir. Ancak eğitim gerçekleştirildikten sonra önişleme tabi tutulmuş EKG verilerinde ekstra bir işlem yapmadan geri-dönüşümlü ağdan çıkan sonuçlar ile son noktanın tespiti yapılabilmektedir. Normal olarak T dalgasının son noktasının bulunması basit bir şekilde $\mathrm{T}$ dalgasının maksimumunun bulunması ile filtrelenmiş dalganın tespiti ile yapılabilmektedir. Ancak bunun için sıklıkla maksimum ve minimum noktalarının sıralı bir şekilde incelenmesi ve bu değerlere göre eğim parametrelerinin de işlemin içine alınarak belirli bir sıra ile verilerin analiz edilmesi gereklidir [7]. Kümeleme diyagramının amacı bu tür noktalardan kurtulmak ve bazı yerlerde filtrelenmiş verilerinin maksimumunda bazı kayıtlarda ise minimumunda oluşan bu ikiliği ortadan kaldırmaktadır. Çünkü kümeleme diyagramında tek bir vektör olarak ifade edilen bu noktalar T dalgasının geri-dönüşümlü sinir ağından çıkan işlenmiş değerlerden sonra minimumda oluşacak bir gevşeme son noktası oluşacağını garanti altına almaktadır (Bakınız Şekil-3). Bütün bu sebeplerden dolayı kümeleme diyagramlarının ve zamana bağlı sinyalleri öğrenebilen geri-dönüşümlü ağların kullanımı çok büyük önem arz etmektedir.

Algoritmanın performansının diğer algoritmalar ile karşılaştırılması ne yazık ki mümkün değildir, çünkü sadece pozitif T dalgası işlenen veya bu çalışma da seçilen kayıtlar üzerinden yapılan bir test metodu bulunmamaktadır. Ancak algoritmanın genel kabiliyeti diğer algoritmalar ile karşılaştırılabilir. Türevsel yöntemlere göre dalganın genliği, genişliği önem arz etmektedir, ve değişen $\mathrm{T}$ dalgası kalıpları için sorunlar çıkarabilmektedir. Ancak GDSA ile bulunan $\mathrm{T}$ dalga kalıpları öğrenildiğinden dolayı genlik ve zaman değerlerine bağlı olarak varyasyonlar çok az olarak gerçekleşmektedir. Diğer yandan belirli bir setin geri-dönüşümlü olarak öğrenilmesi ne yazık ki sonuçların belirli bir kalıp içinde sınırlandırılmasını şart koşmaktadır. Bu yüzden doğru seçimin yapılabilmesi için geri-dönüşümün doğru sayıda yapılabilmesi için arada en az sayıda bağ arada kurulmuştur (3 geri-dönüşüm). Bu koşulun işletilmesi ile sağlanan asıl kazanç, verilerin sadece bir önceki EKG verilerine bağlı olmasını sağlamaktır. Arada daha fazla ağ bulunduğundan algoritma eğitilen kayıtlar için efektif bir şekilde çalıştırılabilmekte, ancak farklı bir set kullanıldığında katsayıların değerleri çok yüksek olduğundan dolayı, yani agresif bir yapısı bulunduğundan dolayı performansta düşüş yaşanmaktadır. Diğer yandan frekans tabanlı yöntemler ile karşılaştırıldığında, T dalgasının son noktasının düşük frekans bandında gerçekleşmesinden ve EKG sinyali için pek çok verinin düşük bir frekans bandında bulunmasından dolayı sonuçlar kötüleşmektedir. Bu yüzden işaretlemelerde yüksek performansa çıkılabilse bile, $\mathrm{T}$ dalgasının son noktasının tam olarak işaretlenebilmesi için ekstra olarak QRS-T ve buna bağlı olarak diğer sinyallerin de bulunması gereklidir [9]. Ayrıca gerçek zamanlı uygulamalar için frekans tabanlı yöntemlerin aktif bir biçimde uygulanması pek mümkün gözükmemektedir. Buna istinaden, yapay sinir ağları, özellikle statik ağlar, gerçek zamanlı uygulamalar için büyük bir avantaj olarak karşımıza çıkmaktadır. Geri-dönüşümlü ağların ekstra hafızada tutması ile belli bir hafıza kaybı ve işlem yükü kullanılan işlemciye yüklense de sıralı olarak taranan verilerin uygulamasında büyük bir avantaj sağlamaktadır. 


\section{SONUÇLAR}

$\mathrm{Bu}$ çalışmada, geri-dönüşümlü yapay sinir ağları kullanılarak EKG'nin bulunması en zor noktalarından biri olan $\mathrm{T}$ dalgasının son noktasının, yani kalbin ventriküllerinin gevşemesinin son noktasının tespiti yapılmıştır. Algoritma eş değerlerinden farklı olarak sıralı verileri inceleyebilmekte, filtrelenmeden dolayı oluşan maksimum ve minimum değerlerinden doğru olanı seçebilme kabiliyetine sahiptir.

Algoritmanın sonuçlarının değerlendirilmesi için toplam olarak 3 adet test gerçekleştirilmiştir. Öncelikle geri-dönüşümlü yapay sinir ağı farklı 11 adet kayıttan seçilen veriler 55 atım ile eğitilmiş ve bunlara bağlı olarak toplam 3 adet geri dönüş kümeleme diyagramları incelenerek seçilmiştir. Ayrıca algoritmanın genel yapısını oluşturan geri-dönüşüm ağının ilk katmanına 6 adet nöron, verilen kümeleme diyagramını kapsayacak şekilde seçilmiş, az sayıda nöronla kararlı ve istikrarlı bir ağ oluşturulmaya çalışılmıştır. Bunlara göre eğitilen 11 kayıttan elde edilen 295 atım değerinde $11.16 \pm 6.16$ milisaniye mutlak hata ve $-4.70 \pm 6.64$ milisaniye mutlak olmayan hata değerlerinde işaretleme işlemi gerçekleştirilmiştir. Ayrıca algoritmanın performansının eğitilen kayıtların atımlarının birbirine benzemesinden dolayı iyi çıkması durumu söz konusu olduğundan, farklı 15 kayıttan elde edilmiş 420 ayrı atım üzerinde denenmiş ve sonuç olarak $-6.40 \pm 17.22$ milisaniyelik bir mutlak olmayan hata değerine ulaşılmıştır.

Sunulan algoritmanın daha önce gerçekleştirilen çalışmalardan farklı olarak kümeleme diyagramları ile kullanımı, ve optimum sayıda nöron ile dağılımların ayrılması, ayrıca maksimum ve minimum noktalarının ayrımının kesinleştirilmesi, sunulan metodun yenilikleri arasında sayılmaktadır. Türevsel yöntemlere oranla değişen dalga formlarından etkilenmemekte, ayrıca ekstra işlemlere maruz kalınmamaktadır. Frekans tabanlı yöntemlere nazaran frekans özelliği etkin bir şekilde kullanılamamakta, ancak verilen kalıplar için düşük frekans bölgesinde yapılması beklenen ayrıştırmayı basit bir minimum seçme işlemi ile gerçekleştirebilmektedir.

Sonuç olarak, sıklıkla sıralı kalıpların işlenmesinde kullanılmayan yapay sinir ağları metotlarının EKG gibi bir sinyalde uygulaması gerçekleştirilmiş ve algoritmanın bu alanda kullanılan standartlar sağlayan bir performansta çalıştırılabileceği kanıtlanmıştır.

\section{KAYNAKLAR}

[1] R. J. Goldberg, J. Bengtson, Z. Chen, K. M., Anderson, E. Locati, D.Levy, "Duration of the QT interval and total and cardiovascular mortality in healthy persons (The Framingham Heart Study experience)," The American journal of cardiology, vol. 67, no. 1, pp. 55-58.,1991.

[2] J. P. Martínez, R. Almeida, S. Olmos, A. P. Rocha, P. Laguna "A wavelet-based ECG delineator: evaluation on standard databases," IEEE Transactions on biomedical engineering, vol. 51, no. 4, pp. 570-581, 2004.

[3] M. Işcan, Ş. Sariozkan, A. Yilmaz, \& C. Yilmaz, "Multilead QT interval analysis algorithm based on continuous wavelet transform,' In 4th International Conference on IEEE in Electrical and Electronic Engineering (ICEEE)’ 05, 2017 pp. 318-322.

[4] J. García, L. Sornmo, S. Olmos, P. Laguna "Automatic detection of ST-T complex changes on the ECG using filtered RMS difference series: application to ambulatory ischemia monitoring," IEEE Transactions on Biomedical Engineering, vol. 47, no. 9, pp. 1195-1201, 2000.

[5] I. K. Daskalov \& I. I. Christov, "Automatic detection of the electrocardiogram T-wave end," Medical and Biological Engineering and Computing, vol. 37, np. 3, pp. 348-353, 1999.

[6] Q. Zhang, A. I. Manriquez, C. Médigue, Y. Papelier, M. Sorine, “An algorithm for robust and efficient location of T-wave ends in electrocardiograms," IEEE Transactions on Biomedical Engineering, vol. 53, no. 12, pp. 2544-2552, 2006.

[7] P. Laguna, N. V. Thakor, P. Caminal, R. Jane, H. R. Yoon, A. Bayés de Luna \& J. Guindo, "New algorithm for QT interval analysis in 24-hour Holter ECG: performance and applications," Medical and Biological Engineering and Computing, vol. 28, no. 1, pp. 67-73, 1990.

[8] Y. C. Chesnokov, D. Nerukh, R. C. Glen, "Individually adaptable automatic QT detector," In IEEE Computers in Cardiology, 2006, pp. 337- 340.

[9] C. Y1lmaz, M. İscan, A. A. Y1lmaz, “A Fully Automatic Novel Method to Determine QT Interval Based on Continuous Wavelet Transform,” Journal Journal of Electrical \& Electronics Engineering, vol. 17, no. 1, pp. 31033111, 2017. 
[10] M. İşcan, C. Yilmaz, F. Yiğit, "T-wave end pattern classification based on Gaussian mixture model," In 24th IEEE Signal Processing and Communication Application Conference (SIU), 2016, pp. 1953 - 1956.

[11] M. İşcan \&C. Yılmaz, “QT Zaman Aralığının Gauss Karışım Modeli ve Yapay Sinir Ağı Tabanlı Tespiti,” Ömer Halisdemir Üniversitesi Mühendislik Bilimleri Dergisi, vol. 6, no. 2, pp. 752-762, 2017

[12] D. Hayn, A. Kollmann, G. Schreier, “Automated QT interval measurement from multilead ECG signals,” In IEEE Computers in Cardiology, 2006, pp. 381-384.

[13] G. D. Clifford, M. C. Villarroel, "Model-based determination of QT intervals," In IEEE Computers in Cardiology, 2006, pp. 357-360.

[14] M. M. Gupta, L. J1n, \& N. Homma, Static and Dynamic Neural Networks from Fundamentals to Advanced Theory. New Jersey : A John Wiley \& Sins Inc, 2003, pp. 106.

[15] E. Alpaydin, Introduction to machine learning. USA-Cambridge : MIT press, 2014.

[16] J.M. Lindauer, R.E. Gregg, E.D. Helfenbein, M. Shao, S.H. Zhou, "Global QT measurements in the Philips 12-lead algorithm," Journal of Electrocardiology, vol. 38, no. 1, pp. 90, 2005.

[17] D. Romero, J. P. Martínez, P. Laguna, E. Pueyo "Ischemia detection from morphological QRS angle changes," Journal of Physiological measurement, vol. 37, no. 7, pp. 1004, 2016.

[18] CSE Working Party. "Recommendations for measurement standards in quantitative electrocardiography," Journal of European Heart Journal, vol. 6, no. 10, pp. 815-825, 1985. 